\title{
Role of Microbes in Food and Industrial Microbiology
}

\section{Kumar A $^{*}$}

School of Biotechnology, Devi Ahilya University, India

\section{Editorial}

Microorganisms, particularly the bacteria and fungi, have served humans since hundreds of years for the purpose of food, drugs, and other high-value chemical products. The use of microbes for fermentation is known since Neolithic age. Microbes not only give a good taste, texture and smell to the foods, but also produce certain inhibitory compounds that help in stopping food spoilage thus increasing the storage and safety of food.

Lactobacilli are important in the production of foods that require lactic acid fermentation, notably dairy products [yogurt and cheese], fermented vegetables [olives, pickles, and sauerkraut], fermented meats [salami], and sourdough bread. The use of Lactobacilli in the food industry has a long history, and the functions of the bacteria in the industrial setting have been well studied [1]. The genera important members of this group are Lactobacillus, Leuconostoc, Pediococcus and Streptococcus. These organisms are heterotrophic and generally have complex nutritional requirements due to lacking of many biosynthetic capabilities. Consequently, most species have multiple requirements for amino acids and vitamins [2].

Metchnikoff winner of a Nobel Prize for his pioneering descriptions of phagocytosis, was interested in the ageing process. While modern research on this topic concentrates on the maintenance of non-mutated DNA sequences, Metchnikoff focused on the gut micro-biota as a source of intoxication from within [3]. According to Metchnikoff, the bacterial community residing in the large bowel of humans was a source of substances toxic to the nervous and vascular systems of the host. These toxic substances, absorbed from the bowel and circulating in the bloodstream, contributed to the ageing process. Gut bacteria were thus identified as the causative agents of "autointoxication." The offending bacteria were capable of degrading proteins [putrefaction], releasing ammonia, amines, and indole, which, in appropriate concentrations, were toxic to human tissues. The term 'Probiotic' first coined by Lilley and Stillwell [4] in an entirely different context to describe substances secreted by one type of microorganism that stimulated the growth of another [probiotic to contrast with antibiotic], was subsequently used to describe "organisms and substances which contribute to intestinal microbial balance" [5]. Fuller's definition [6] for probiotic "a live microbial feed supplement which beneficially affects the host animal by improving its intestinal balance," has been widely used. Similary, fungi especially Saccharomyces sps. have found historic use in baking and brewing industry. Particularly S. cerevisiae plays an important role in revenue generation from brewing industry so much so that $S$. cerevisiae was declared official state microbe by the state of Oregon in 2013. Other fungi such as Aspergillus sps. and Penicillium sps. have also found use in food industry particularly due to the enzymes obtained from them [7]. Fungi have an important role in probiotics preparation as well.

The best example of drug production by microbes lies in antibiotics production. The Penicillin was discovered in 1928 by Scottish scientist Alexander Fleming and later several derivatives of it brought a kind of revolution in the world of antibiotics. However in the present time, microbes are used for production of secondary metabolites and combinatorial biosynthesis of drugs, thus paving way for newly discovered antibiotics, such as candin, semisynthetic versions of older antibiotics such as ketolides; older under-utilized antibiotics such as teicoplainins; and new derivatives of older undeveloped narrowspectrum antibiotics such as streptogramins [8]. In addition, many antibiotics are used as antitumor agents, immunosuppressive agents, anti-migraine agents, enzymes inhibitors etc. Another major class of pharmaceutical products obtained from microbes is of recombinant proteins where eukaryotic production system such as yeast is preferred over prokaryotic system due to its ability to carry out post translational modifications in the expressed proteins. The approved protein products produced exclusively in Saccharomyces cerevisiae are hormones [insulin, insulin analogues, non-glycosylated human growth hormone somatotropin, glucagon], vaccines [hepatitis B virus surface antigen - in the formulation of 15 out of the 28 yeast derived products-] and virus-like particles [VLPs] of the major capsid protein L1 of human papilloma virus type $6,11,16$ and 18, urate oxidase from Aspergillus flavus, granulocyte-macrophage colony stimulating factor, albumin, hirudin of Hirudo medicinalis and human platelets derived growth factor [9].

Bio-fuels research has gained momentum due to the fact that natural fuel resources are fast depleting and cannot be replenished. Microbes have an active role to play in production of bio-fuels. The most commonly used bio-fuels are bio-ethanol obtained from starch, fast emerging cellulosic ethanol and biodiesel from vegetable oils. Cellulosic ethanol has gained momentum owing to the easily available non-food and non-fodder raw material in the form of agriculture waste and forest residue. The enzyme cocktails required for hydrolysis of plant cell wall polysaccharides into monomers are derived from microbes and are mainly comprised of glycoside hydrolases [10]. The fermentation of these monomers into ethanol requires the use of microbes particularly yeast and coli [11]. Many other approaches such as Consolidated Bioprocessing [CBP] [12], Simultaneous Saccharification and Fermentation [SSF] [13], are being attempted in order to bypass the need for expensive enzyme cocktails. Such processes require microbes that can be developed either by engineering of the native cellulolytic mechanism of the microbe to improve product related properties, or by engineering a non-cellulolytic organism that exhibits high product yield and titer by expressing heterologous cellulose system [14]. Besides, microbes such as Clostridia are being developed for improved production of advanced fuels such as butanol and isopropanol which are considered superior fuels than ethanol due to higher energy density and being non-hygroscopic in nature [15].

*Corresonding author: Kumar A, Professor, School of Biotechnology, Devi Ahilya University, India, Tel: 07312527532; E-mail: ak_sbt@yahoo.com

Received July 19, 2016; Accepted July 22, 2016; Published July 26, 2016

Citation: Kumar A (2016) Role of Microbes in Food and Industrial Microbiology. J Food Ind Microbiol 2: e101. doi:10.4172/2572-4134.1000e101

Copyright: (c) 2016 Kumar A. This is an open-access article distributed under the terms of the Creative Commons Attribution License, which permits unrestricted use, distribution, and reproduction in any medium, provided the original author and source are credited. 
The huge amount of data available from various genomic, transcriptomic, proteomic and metabolomic studies has paved ways to engineer and program microorganisms to produce desirable fuel and other products of commercial importance. Synthetic biology allows design and construction of new genetic parts such as promoter, transcription factors, ribosomal binding sites, degradation tags and transcriptional terminators that do not exist in nature but can be assembled and used for reprogramming biological systems to our advantage [16]. Microbial production of chemicals presents an alternative to ubiquitous chemical synthesis methods. Biosynthetic production is attractive because it can use a broad assortment of organic feed stocks, proceed under benign physiological conditions, and avoid environmentally deleterious byproducts. Biosynthetic alternatives are being pursued for a wide range of chemicals, from bulk commodity building blocks to specialty chemicals. Fortunately, natural sensors exist for a wide array of industrially relevant chemicals, including aliphatic hydrocarbons, short-chain alcohols, sugars, amino acids, polymer building blocks, and vitamins [17]. Microbes can be exploited in industries for production of various products useful to human and other animals. By way of engineering the microbes, there are more possibilities to exploit microbes in a better way.

\section{References}

1. Jay JM (1996) Modern food microbiology (5thedn) Chapman and Hall, New York.

2. Zacharof MP, Lovitt RW, Ratanapongleka K (2010) The importance of Lactobacilli in contemporary food and pharmaceutical industry-A review article. Academia.

3. Metchnikoff E (1908) The nature of man: Studies in optimistic philosophy. William Heinemann, United Kingdom.

4. Lilley DM, Stillwell RH (1965) Probiotics: growth promoting factors produced by microorganisms. Science 147: 747-748.
5. Parker RB (1974) Probiotics, the other half of the antibiotic story. Anim Nutr Health 29: 4-8.

6. Gionchetti P, Rizzello F, Helwig U, Venturi, A, Lammers KM, et al. (2003) Prophylaxis of pouchitis onset with probiotic therapy: a double-blind, placebocontrolled trial. Gastrenterology 124: 1202-1209.

7. Semenova MV, Sinitsyna OA, Morozova VV, Fedorova EA, Gusakov AV, et al (2006) Use of a preparation from fungal pectin lyase in the food industry. Appl Biochem Microbiol 42: 598-602.

8. Zhang L, Demain, AL (2005) In Natural Products-Drug Discovery and Therapeutic Medicine. Springer publications New York.

9. Miralles NF, Espín JD, CorcheroJL, Vázquez E, Villaverde A (2009) Microbia factories for recombinant pharmaceuticals. Microbial Cell Factories.

10. Gilbert HJ (2010) The Biochemistry and Structural Biology of Plant Cell Wall Deconstruction. Plant Physiol 153: 444-455.

11. Zhang GC, Lui JJ, Ding WT (2012) Decreased xylitol formation during xylose fermentation in Saccharomyces cerevisiae due to overexpression of WaterForming NADH Oxidase. Appl Environ Microbiol 78: 1081-1086.

12. Lynd LR, vanzyl WH, McBride JE, Laser M (2005) Consolidated bioprocessing of cellulosic biomass. Biotechnology 16: 577-583.

13. Olofsson, K, Bertilsson, M, Liden G (2008) A short review on SSF - an interesting process option for ethanol production from lignocellulosic feedstocks. Biotechnol Biofuels. 1: 7.

14. Parisutham V, Kim TH, Lee SK (2014) Feasibilities of consolidated bioprocessing microbes: From pretreatment to biofuel production. Bioresource Technology 161: 431-440.

15. Dusséaux S, Croux C, Soucaille P Meynial-Salles I (2013) Metabolic engineering of Clostridium acetobutylicum ATCC 824 for the high-yield production of a biofuel composed of an isopropanol/butanol/ethanol mixture. Metabolic Engineering 18: 1-8.

16. Singh V (2014) Recent advancements in synthetic biology: Current status and challenges. Gene 535: 1-11.

17. Raman S, Rogers JK, Taylor ND, Church GM (2014) Evolution-guided optimization of biosynthetic pathways. Proc Natl Acad Sci USA 111: 17803-17808. 